\title{
sciendo
}

10.2478/msd-2019-0008

\section{DEVELOPING CULTURAL INDUSTRIES IN CENTRAL AND EASTERN EUROPEAN COUNTRIES}

\author{
Marta-Christina, SUCIU ${ }^{1}$, Christian, NĂSULEA ${ }^{2}$ and Diana, NĂSULEA ${ }^{3}$ \\ Bucharest University of Economic Studies, mcsuciu50@gmail.com \\ University of Bucharest, Faculty of History, christian@nasulea.ro \\ Bucharest University of Economic Studies, diana@nasulea.ro
}

\begin{abstract}
In recent years, culture became an important source of revenue and employment with a significant impact on sustainable development and the quality of life. As developing cultural industries is one of the Europe 2020 Agenda objectives, countries are supporting the creative sectors whose positive outputs lead to new jobs and economic growth. This paper aims to give an overview of the current state of Romanian cultural industries by comparison to other Central and Eastern European countries. Firstly, it starts with outlining the conceptual positions on culture and creativity, followed by a discussion on the theoretical aspects concerning cultural industries and their impact on prosperity and growth. We will look at the business sector, labour market, cultural vitality and participation within cultural industries to assess both the potential and the trends for development
\end{abstract}

KEY WORDS: cultural industries; creativity; development; sustainability.

\section{INTRODUCTION}

The early 80s have witnessed the emergence of a new economy whose focus was set on the manufacturing of hightechnologies, artisanal consumer products and new services promising to change the structure of modern capitalist systems through added value. Lying at the brim of the clash between economic expansion and human expression, cultural sectors produce a large variety of outputs, such as visual arts. dance, music, video games, movies and television, new media, fashion or architectural design [1].

Culture lies at the core of Europe's history, identity and set of values. Supporting culture was a priority of the Lisbon Treaty and developing cultural industries became a clear goal of the EU through the European Agenda for Culture [2]. In recent years, culture has become one of the main sources of profit, employment and economic growth [3]. The importance of cultural products is not only an economic one, although their contribution to GDP is rapidly increasing, but also sociological, as cultural goods play a key role in citybranding, therefore also in tourism and in increased living standards [4]

The main issue with understanding cultural industries revolves around trying to define what they are and what they mean. There is some kind of common understanding that the result of cultural sectors is shaped by goods and services with an aesthetic or expressive content [5]. However, finding a strict and specific definition for a field whose core substance is volatile and in continuous change can bring a series of theoretical dilemmas. The characteristics of these industries are nevertheless abstract and unconventional. Firstly, the products derived from cultural industries are subjectively valued from the perspective of user's experience with them, rather than for a specific functional utility [4]. This means that a cultural product brings different amounts of value for different individuals, and this value can range drastically depending on factors such as personal preferences, level of education, cultural background, environment, age and so on.
Nonetheless, drawing a line between utilitarian outputs and cultural products is almost impossible, as different goods can indeed fall in the two categories. Secondly, as Power \& Scott [1] suggest, cultural sectors growth follows the Engels' Law, meaning that as individuals' disposable income increases, the consumption of so-called luxury goods will rise, thus developed cultural industries become an attribute of prosperous societies [1]. Thirdly, cultural industries have developed within competitive organizational frameworks, meaning that they tend to exist in dense places where creativity inspires more creativity, while their outputs tend to spread globally determining trends and influencing societies. This third aspect explains why big multicultural urban communities such as London or Berlin became creative hubs. A fourth aspect refers to a concept we've mentioned before, creativity, as the basis of cultural industries. Creativity stood at the core of all historical innovation, so it would be a mistake to consider the creative process a revolutionary attribute of the 21 st century economic development. What is indeed different than before, is the approach towards creativity as a globally spread collective process of individuals using their talent and cognitive skills in order to put culture to work, through commercial innovations [6].

These main four characteristics tend to also represent the guidelines for understanding the framework for developing cultural industries. The first one refers to a measurement problem [7], as cultural products are subjectively perceived. The last characteristics show that (a) cultural industries appear in areas where there is a certain level of economic prosperity, so people can focus on the top of Maslow's [8] hierarchy of needs; (b) a higher level of education is needed for both the creation and the consumption of cultural products (c) cultural industries develop within multicultural urban societies and (d) a propitious legal framework is needed in order to allow for individuals to express their talent through commercial activities. These are some of the main prerequisites for developing cultural industries, but they are not the only ones. European countries tend to have cities that 
fit this description. However, some of them have a more vivid creative sector than others.

We will look at how Romanian cultural industries score in comparison to other CEE countries in order to determine on one hand the main aspects whose change can improve the current state of these sectors and on the other hand, the impact of cultural products and cultural consumption on the overall economic growth and wellbeing of Romanian people.

\section{METHODOLOGY}

As we have mentioned before, measuring cultural industries and their impact is no easy task. This research focuses on analysing cultural industries in Central and Eastern European (CEE) countries. We have chosen the OECD definition of this area as comprising Bulgaria, Croatia, the Czech Republic, Hungary, Poland, Romania, Slovakia, Slovenia and the three Baltic states: Estonia, Latvia and Lithuania [9]. We excluded Albania from our research as national data could not be compared to Eurostat data. The CEE countries have been selected because of their similarities in cultural background and economic development. The main focus of the paper will be to analyse Romanian cultural industries, through the perspective of regional development. In order to be able to make cross-country comparisons, we will use the Eurostat statistics on the following indicators:

- Cultural enterprises - structural business statistics with regard to cultural enterprises show how big is the market for cultural products. We will look at the number of companies, turnovers and size in order to determine the potential impact of these industries on economic growth

- Cultural Employment. The EU Labour Force Survey measures the number of people employed in the cultural economic sector, irrespective of they are employed on a cultural-related position of not. Although this might not give a perfect image of the real number of people working in these sectors, this database is the only one respecting the same NACE classification, thus giving the

Table 1. Key indicators on cultural enterprises and those in total business economy services, 2013 [13]

\begin{tabular}{|c|c|c|c|c|c|c|c|c|}
\hline & \multicolumn{3}{|l|}{ Cultural enterprises } & \multicolumn{2}{c|}{$\begin{array}{c}\text { Persons employed } \\
\text { per enterprises } \\
\text { (average no.) }\end{array}$} & \multicolumn{2}{c|}{$\begin{array}{c}\text { Turnover (gross } \\
\text { premium written }\end{array}$} & \multicolumn{2}{c|}{$\begin{array}{c}\text { AAR of turnover } \\
(2008-13)\end{array}$} \\
\hline & number & $\begin{array}{c}\text { \% of total } \\
\text { services }\end{array}$ & $\begin{array}{c}\text { in } \\
\text { culture }\end{array}$ & $\begin{array}{c}\text { in total } \\
\text { services }\end{array}$ & $\begin{array}{c}\text { million } \\
\text { EUR }\end{array}$ & $\begin{array}{c}\text { \%of total } \\
\text { services }\end{array}$ & $\begin{array}{c}\text { in } \\
\text { culture }\end{array}$ & $\begin{array}{c}\text { in total } \\
\text { services }\end{array}$ \\
\hline Bulgaria & 4834 & 4 & 3.7 & 4.9 & 614 & 3.8 & -3.3 & 1.6 \\
\hline Croatia & 3479 & 5.3 & 4.5 & 5.3 & 856 & 5.5 & -5.2 & -1 \\
\hline $\begin{array}{c}\text { Czech } \\
\text { Republic }\end{array}$ & 20198 & 5.3 & 1.7 & 2.8 & 2712 & 3.8 & -5.2 & \\
\hline Estonia & 1672 & 5.3 & & 6.8 & & & & 4.4 \\
\hline Hungary & 12633 & 5 & 2.2 & 3.6 & 2519 & 5.1 & -1.1 & -2.3 \\
\hline Latvia* & 1918 & 3.9 & 3.8 & 4.6 & 255 & 2.2 & & 1.8 \\
\hline Lithuania & 1705 & 3.2 & 5.6 & 5.6 & 325 & 2.3 & -10.3 & 3.2 \\
\hline Poland & 35071 & 6.2 & 3 & 4.2 & 7893 & 6.2 & -4 & 0.8 \\
\hline Romania & 8621 & 5.3 & 4.6 & 7.1 & 1360 & 3.6 & -8.1 & -1 \\
\hline Slovakia** & 4346 & 3.4 & 2.4 & 3.3 & 709 & 2.7 & & 9 \\
\hline Slovenia & 4531 & 7.3 & 2 & 3.1 & 649 & 4.3 & & -0.6 \\
\hline Average & 9000.73 & 4.93 & 3.35 & 4.66 & 1789.20 & 3.95 & -5.33 & 1.21 \\
\hline
\end{tabular}

The effects of financial crises on cultural industries are yet to be explored. Some authors follow the normative economic logic suggesting that cultural and creative industries have high income elasticity [14] so they will be more affected by crisis than regular industries while others argue for the opposite [15]. However, cultural industries remain a priority for the EU even possibility of making comparisons. This survey is based on a classification comprising 9 NACE codes for the cultural sectors as economic activities and 21 ISCO-08 categories of cultural occupations [10]

- Government expenditure on cultural services

- Private Expenditure on culture - the mean consumption expenditure of private households on cultural goods and services will be analysed in order to determine individuals' level of involvement in consuming cultural products

- Cultural participation by socioeconomic background cultural participation affects the general quality of life and people's wellbeing, thus understanding the main variables that impact cultural participation is a necessity. An analysis of cultural participation by education attainment level and income will be conducted

\section{RESULTS}

Cultural industries have a significant impact on economic growth from both the perspective of creating jobs and facilitating human development as a result of their impact on social, organizational and institutional evolution [11].

\subsection{Overview of Cultural Enterprises in CEE Countries}

In 2013 there were around 99000 cultural enterprises in the CEE countries with a turnover of 17 billion EUR. The turnover as share of total services is apparently low but this can be explained through the average size of cultural enterprises being smaller than the average service enterprise (2-3 persons employed in cultural enterprises compared as opposed to 5 in generic service enterprises) [12]. Lithuania was the only EU member state in which the average number of people employed per enterprise was equal in cultural sectors to services (Table 1). 
hit cultural sectors a lot harder than other services, the AAGR of turnovers having an average negative growth in the CEE countries of $-5.3 \%$ in cultural sectors and a positive increase in total services (1.21\%). According to Table 1, Lithuanian and Romanian cultural enterprises were hit very hard, the AAGR of turnovers in cultural sectors decreasing by $10 \%$ and $8 \%$. This could be explained through the fact that cultural products are luxury goods, so a decrease in people's income will automatically influence services that are not of basic need for individuals.

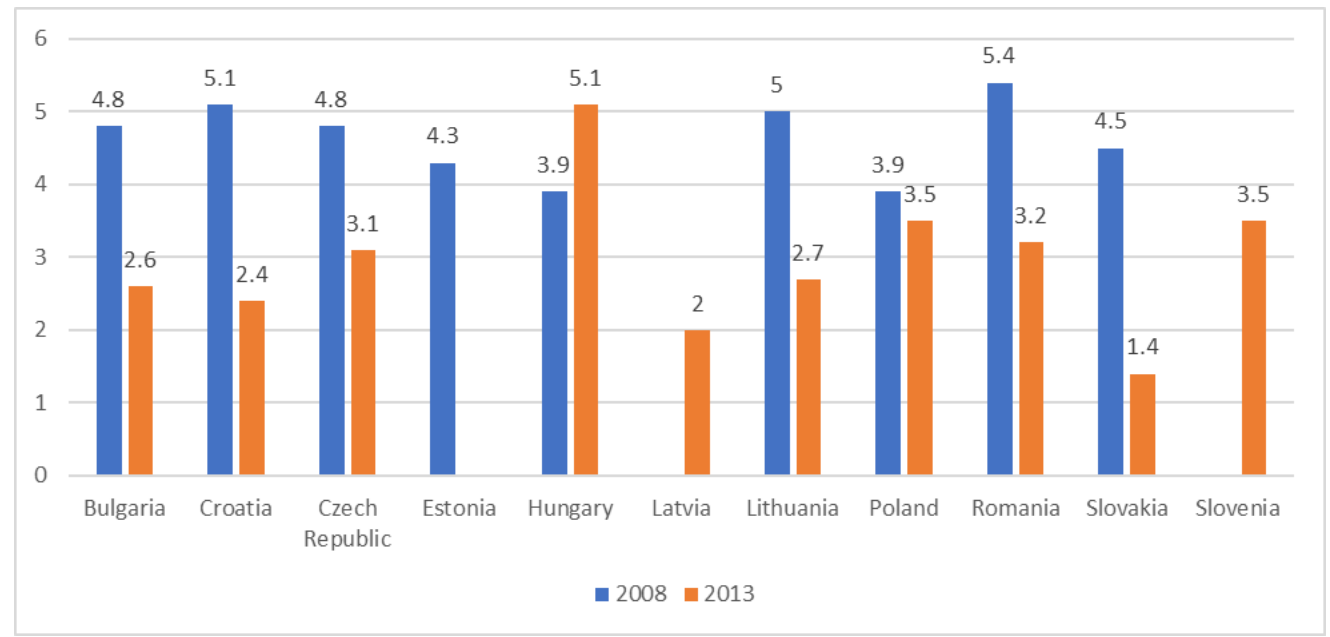

Figure 1. Value added in cultural sectors, 2008 and 2013 (\% of value added in total services). [13]

The effects of the financial crisis can also be seen in the decrease of value added in cultural sectors, which fell, with the exception of Hungary, with almost $2 \%$ in all CEE countries. The most affected sectors were news publishers, while computer games, design activities and the movie industry were still on a steady rise [12].

\subsection{Cultural Employment}

Cultural industries and the existence of a creative class [16] are considered to be the future of developed nations. Cultural and creative workers are usually characterised as young, highly productive, entrepreneurial and independent, and highly educated. [17]. Cultural employment is a useful measurement of both the size of creative industries and the involvement of individuals with the creative sectors in order to grasp culture's contribution to socio-economic development. Cultural occupations in the EU refer to writers, journalists, librarians, performing artists, handcraft workers and graphic designers [12]. Referring to the sectors, the cultural activities embrace arts and entertainment, design, programming, sound production etc. [12].

In 2016 in the EU there were more than 8 million cultural jobs, amounting for $3.7 \%$ of total employment at EU level. Of this, almost $1.5 \%$ of the cultural jobs were located in CEE countries. However, the distribution across CEE countries is far from even. As shown by Fig. 2. Estonia and Slovenia are leading with cultural occupations representing $5.3 \%$ and $4.6 \%$ of total employment at national level. Cultural employment in Romania is under the CEE average, with only $1.6 \%$ of the people employed in cultural jobs which is surprising given that the turnover of cultural enterprises is significantly larger in Romania than in Bulgaria, Croatia, Latvia and Lithuania (Table $1)$.

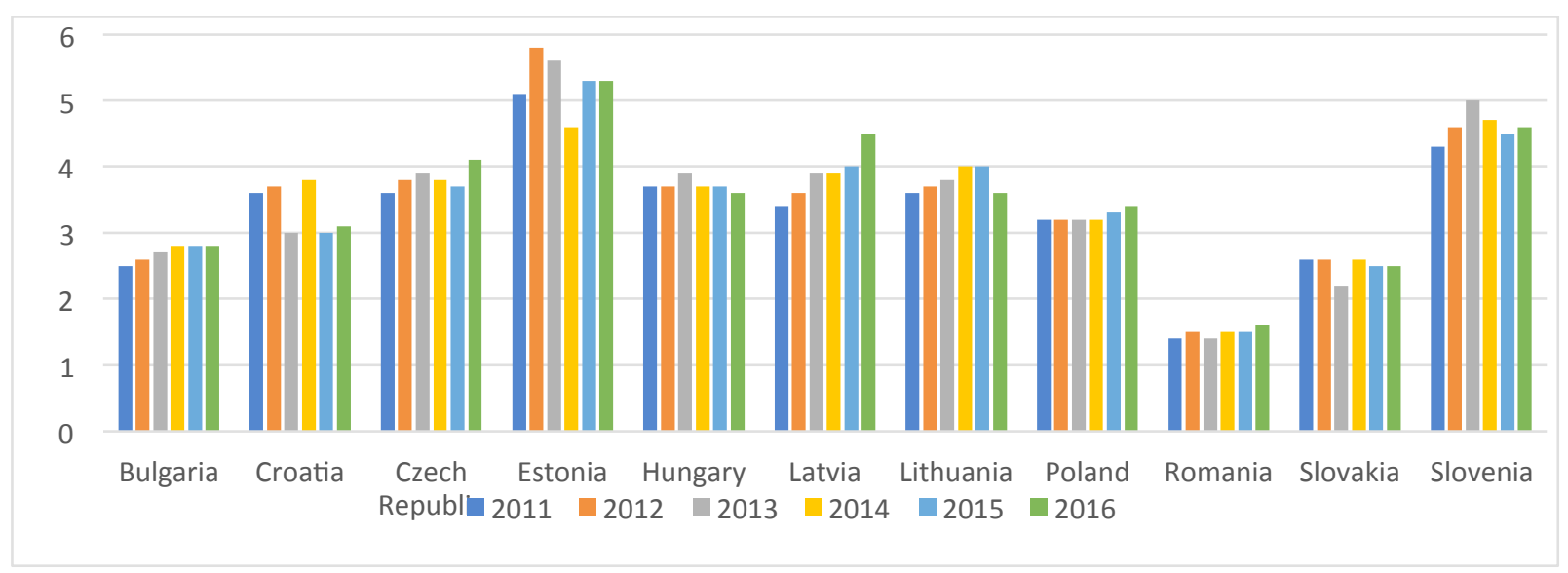

Figure 2. Cultural employment (\% of total employment) 2011-2016 [13]

During 2011-2016 the number of people employed in cultural activities had a relatively high increase in the share of cultural employment in Latvia from $3.4 \%$ to $4.5 \%$. Bulgaria also had a small but steady increase from $2.5 \%$ to $2.8 \%$, as well as the Czech Republic. The share increase in Romania was small, amounting only $0.2 \%$ over the 6 years period.

\subsection{Government expenditure}

CEE countries tend to be rather consistent about their spending with cultural services. For instance, Latvia and Estonia consistently spend more than $1 \%$ while all the other CEE countries consistently spend less. Romania is also quite consistent at being last on the list spending $0.4 \%$ or less. 
Bulgaria was the only country to spend less, for one year in 2009 , when spending was only $0.3 \%$. Since then, however,

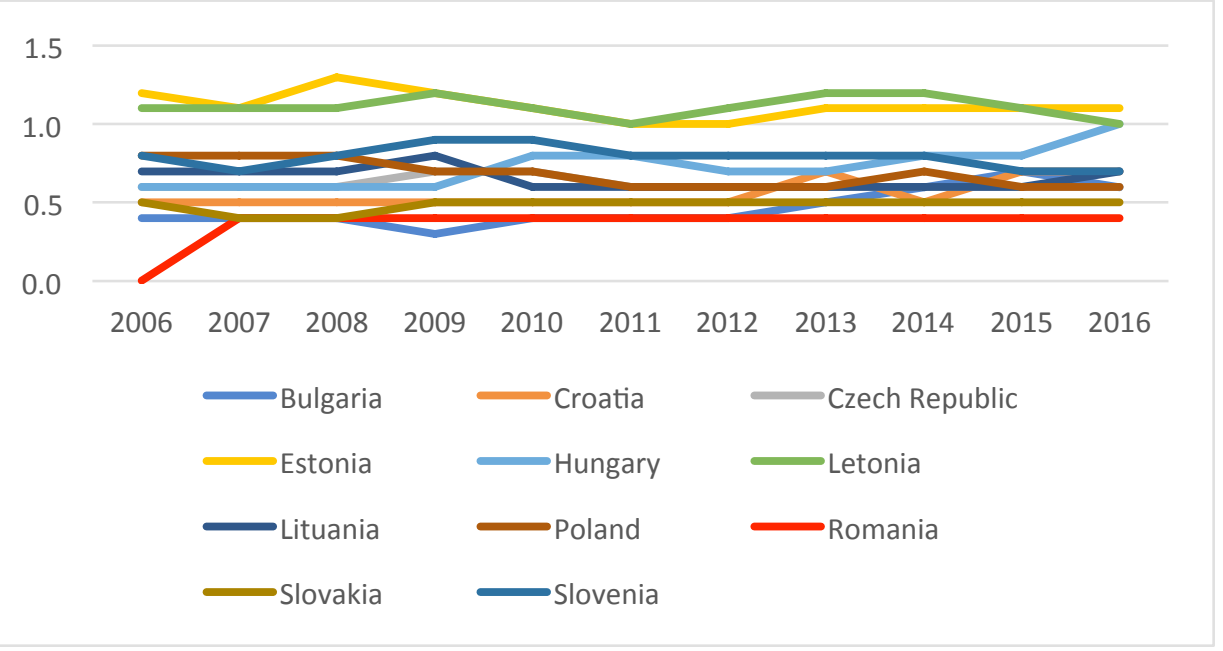

\subsection{Cultural participation}

Figure 3. General government expenditure by cultural services (2006-2016) [13].

Cultural participation is considered to reflect the purpose of cultural industries, while also predicting the well-being of individuals and the quality of life.

Table 2. Frequency of participation in cultural activities in the last 12 months (2015) [13].

\begin{tabular}{|c|c|c|c|c|}
\hline & $\begin{array}{c}\text { Cultural } \\
\text { activities } \\
\text { (all) }\end{array}$ & Cinema & $\begin{array}{c}\text { Live } \\
\text { performances }\end{array}$ & $\begin{array}{c}\text { Cultural } \\
\text { sites }\end{array}$ \\
\hline Bulgaria & 28.6 & 21.7 & 19.4 & 14.6 \\
\hline Croatia & 36.6 & 24.9 & 26.3 & 19.2 \\
\hline $\begin{array}{c}\text { Czech } \\
\text { Republic }\end{array}$ & 70.2 & 47.8 & 48.0 & 52.1 \\
\hline Estonia & 69.8 & 48.2 & 56.2 & 44.2 \\
\hline Hungary & 50.0 & 30.8 & 31.0 & 34.8 \\
\hline Latvia & 63.3 & 31.8 & 52.4 & 44.2 \\
\hline Lithuania & 62.0 & 34.9 & 56.7 & 31.2 \\
\hline Poland & 53.7 & 41.1 & 25.9 & 37.8 \\
\hline Romania & $\mathbf{2 7 . 4}$ & $\mathbf{1 9 . 3}$ & $\mathbf{2 1 . 4}$ & $\mathbf{1 8 . 3}$ \\
\hline Slovakia & 59.4 & 35.1 & 40.3 & 33.7 \\
\hline Slovenia & 70.1 & 36.7 & 56.8 & 43.8 \\
\hline Average & $\mathbf{5 3 . 7}$ & $\mathbf{3 3 . 8}$ & $\mathbf{3 9 . 5}$ & $\mathbf{3 4 . 0}$ \\
\hline
\end{tabular}

We analyse three cultural activities reflected in cultural participation and consumption: attendance at live performances such as theatre, concerts and ballet, going to the cinema, and visiting cultural sites such as historical monuments, museums, art galleries or archaeological sites.

In 2015, attending live performances was the leading activity in almost all CEE countries, except Bulgaria (Table 2). However, Romanians' participation in cultural activities is almost half the CEE countries average, which places Romania on the last position, after Bulgaria.

These results can be somehow correlated to the standard of living and people's disposable income for cultural activities. If we look at Fig. 4 we can see a similar pattern, meaning that countries with a low GDP/capita exhibit lower cultural participation.

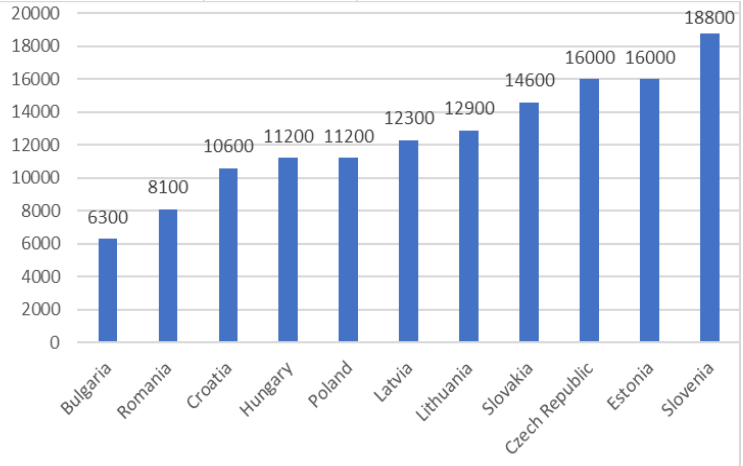

Figure 4. GDP at market prices (EUR/capita) [13].

Further on, education is another factor that influences cultural participation. Educated people are more prone to be interested in attending cultural activities, because (a) they can afford to do it and (b) they can appreciate fine art at a higher level than uneducated individuals. According to Fig. 5, the majority of the people attending cultural activities has some tertiary education. However, in less economically developed countries such as Bulgaria and Romania, we can see only a few people with less than primary, primary and lower secondary education are involved in such activities.

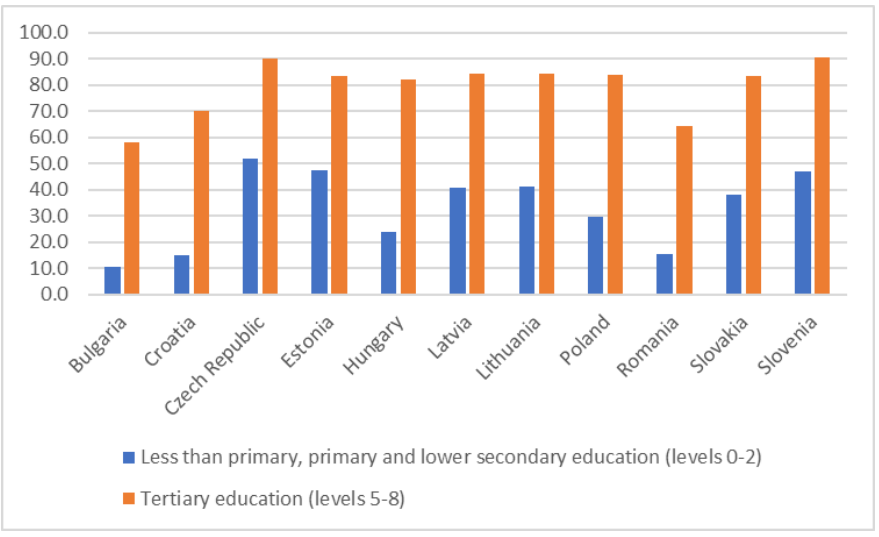

Figure 5. Frequency of participation in cultural or sport activities in the last 12 months by education level 2015 [13].

By looking at mean consumption expenditure on cultural goods we can once again observe Romania and Bulgaria at the back of the queue. Detailed data from Eurostat, presented in Table 3, gives us valuable insight into what it is exactly among cultural 
Table 4. Mean consumption expenditure of private households on cultural goods and services by COICOP consumption purpose, 2010 (part 1) [13].

\begin{tabular}{|c|c|c|c|c|c|c|c|c|}
\hline & Total & $\begin{array}{c}\text { Cultural goods } \\
\text { and services }\end{array}$ & \multicolumn{2}{|c|}{ Foto-video equipment } & IP equipment & \multicolumn{2}{|c|}{$\begin{array}{c}\text { Recording media \& } \\
\text { processing equipment }\end{array}$} & \multicolumn{2}{c|}{$\begin{array}{c}\text { Musical } \\
\text { instruments }\end{array}$} \\
\hline BG & 9,334 & 155.7 & 4.1 & 0.9 & 6.4 & 0.9 & 2 & 0 \\
\hline HR & 17,264 & 498.8 & 27.4 & 3.1 & 19.2 & 3.9 & 0.4 & 0.9 \\
\hline CZ & 13,161 & 614.7 & 85.9 & 15.8 & 74.7 & 23.5 & 8.3 & 4.1 \\
\hline EE & 10,421 & 380.3 & 68.3 & 13.3 & 58.3 & 11.8 & 3.9 & 5 \\
\hline HU & 14,017 & 467.5 & 29.6 & 7.3 & 36.7 & 8.3 & 1.9 & 0.8 \\
\hline LV & 11,381 & 369.4 & 49 & 8.4 & 23.6 & 7 & 3.8 & 2.4 \\
\hline LT & 14,730 & 310.7 & 24.5 & 8.2 & 53.2 & 9.6 & 4.3 & 0.8 \\
\hline PL & 15,263 & 670.8 & 58.5 & 14.8 & 40.3 & 13.3 & 4.7 & 2.9 \\
\hline RO & 9,623 & 201.5 & 11.7 & 1.8 & 6.1 & 0.9 & 1 & 0 \\
\hline SK & 15,041 & 442.7 & 61.7 & 10.7 & 28.7 & 9.6 & 3.7 & 1 \\
\hline SI & 25,514 & 913.4 & 102 & 25.3 & 89.5 & 17.6 & 2.6 & 21.7 \\
\hline Avg & 14,159 & 457 & 48 & 10 & 40 & 10 & 3 & 4 \\
\hline
\end{tabular}

goods and services that drives down the numbers for these countries. Essentially, the two countries perform lower than all others on all counts except for Licenses and Fees

As expected, income is directly correlated to cultural participation. As shown in Fig. 6 there is a very high difference

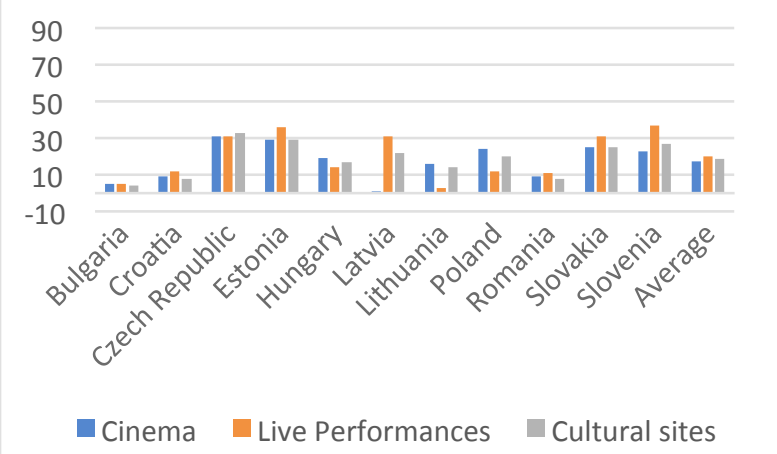

between the percentage of individuals with income in the first and the fifth quintile attending cultural activities.

As expected, income is directly correlated to cultural participation. As shown in Fig. 6 there is a very high difference between the percentage of individuals with income in the first and the fifth quintile attending cultural activities

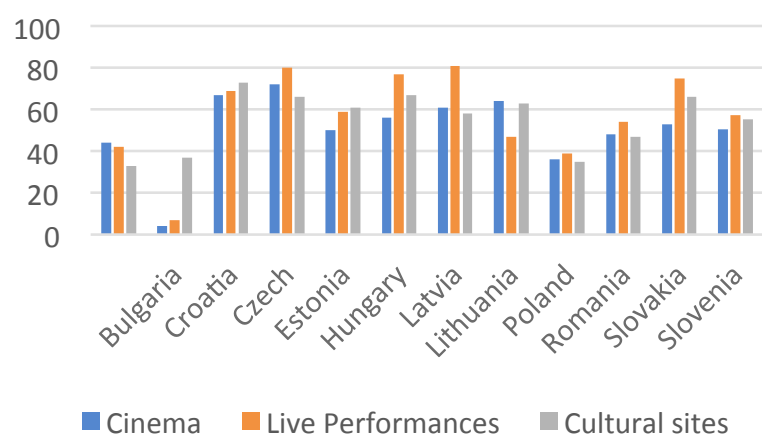

Figure 6. Cultural participation of people with income in the first and the fifth quintile, by cultural activity, 2015 (\% of population aged 16 and over) [13]

Table 5. Mean consumption expenditure of private households on cultural goods and services by COICOP consumption purpose, 2010 (part 2) [13]

\begin{tabular}{|c|c|c|c|c|c|c|c|}
\hline & $\begin{array}{c}\text { Museums, } \\
\text { libraries, } \\
\text { zoological gardens }\end{array}$ & $\begin{array}{l}\text { Licenses } \\
\text { fees }\end{array}$ & \multicolumn{2}{|c|}{$\begin{array}{c}\text { Books \& } \\
\text { Newspapers }\end{array}$} & $\begin{array}{c}\text { Stationery and } \\
\text { drawing materials }\end{array}$ & $\begin{array}{c}\text { Live } \\
\text { performances }\end{array}$ & Entertainers \\
\hline BG & 0.5 & 93.2 & 12 & 21.3 & 8.7 & 4.6 & 1.2 \\
\hline HR & 1.6 & 183.1 & 103 & 86.7 & 31.1 & 28.4 & 8.5 \\
\hline $\mathrm{CZ}$ & 18.5 & 157.6 & 55 & 79.9 & 17.3 & 53.8 & 10.7 \\
\hline $\mathrm{EE}$ & 3.4 & 33.3 & 50 & 59.3 & 12.8 & 37.3 & 19 \\
\hline $\mathrm{HU}$ & 4.6 & 194.7 & 63 & 60.8 & 28.2 & 24.5 & 2.3 \\
\hline $\mathrm{LV}$ & 4.1 & 96.9 & 35 & 79.1 & 18.2 & 32 & 7.8 \\
\hline LT & 8.7 & 52.2 & 35 & 47.5 & 20.3 & 32.4 & 4.9 \\
\hline PL & 3.1 & 300.6 & 75 & 46.8 & 28.8 & 23.4 & 48.9 \\
\hline $\mathrm{RO}$ & 0.4 & 120.9 & 13 & 37.2 & 2 & 4.6 & 0.7 \\
\hline SK & 2.1 & 154.7 & 39 & 73.5 & 26.1 & 21.2 & 5.6 \\
\hline SI & 4.6 & 328.2 & 60 & 162 & 53 & 20 & 17.9 \\
\hline Avg & 5 & 156 & 49 & 69 & 22 & 26 & 12 \\
\hline
\end{tabular}

While we can hint at correlation or even proportionality between income and participation in cultural activities, there are also other important factors that help to explain the low numbers for some CEE countries. As shown in Fig. 7
Romanians claim that lack of cultural facilities is the single most important reason for not participating in cultural activities. 


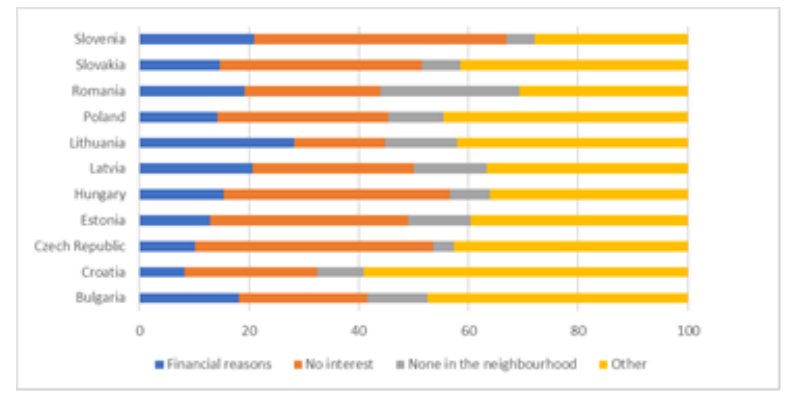

Figure 7. Reasons for not participating in cultural activities (cinema, cultural sites, live performances [13].

\section{CONCLUSIONS}

Culture and creativity are the tools we need to communicate higher values, create stronger communities and develop in an efficient and sustainable manner. Even though cultural industries are a strategic priority of the European Union, their size and output are spread differently across countries. Central and Eastern European countries are known for the creativity and talent of their people, but these qualities are not always reflected by data.

Romanian cultural industries perform significantly worse in almost all aspects compared to those of its neighbours. First of all, the main issues blocking cultural industries are related to economic development, cultural employment and cultural participation. We believe the three to be inseparable as cultural participation and interest for cultural activities is what determines more people to be involved in these industries and transform their talent into economic activities. Understanding the causes that lead to a low level of cultural participation should be the first step towards improving the situation for both cultural workers and their public.

One first challenge for CEE countries and especially Romania is the brain-drain phenomenon. Unfortunately, talented people are the first to leave CEE countries for places with better opportunities. This problem is usually correlated with the low living standard in some of these countries and a general sentiment of disappointment towards people's native countries. As a result, highly educated people who can aim for better paid jobs would either pursue their dreams somewhere else or would give up a low paid creative job for something more traditional and better paid, which leads to another phenomenon, namely brain-waste. In countries with a weakened level of human capacities and education, this will lead to a lack of professionals in cultural industries, which translates to poorly prepared cultural managers, bad communication strategies and a generalised lack of understanding with regards to cultural fields [18].

However, Central-Eastern Europe is a region with a rich and diverse cultural heritage, talented people and high potential for growth. Further development should be based on public policies that allow for cultural sectors to develop in a friendly environment. Recognizing not only the social and historical importance of culture, but also its economic side will lead to a sustainable development model that respects the specificity of each country while also allowing for its cultural products to become of global importance.

Further research should focus on in-depth analysis of cultural participation in CEE countries, examining attitudes of individuals with respect to cultural industries as a step towards shaping public policies that will create a better framework for talented people.

\section{REFERENCES}

1. Power, D., Scott, A.J., A prelude to cultural industries and the production of culture. In D. Power, \& A. J. Scott (Eds.), Cultural Industries and the Production of Culture, pp. 3-16, New York, Routledge (2004).

2. EU Publications Office, European agenda for culture in a globalising world (2010). Retrieved 13.03.2018, from http://eur-lex.europa.eu/legal-

content/EN/TXT/?uri=LEGISSUM\%3A129019

3. Brandellero, A., Kloosterman, R., Keeping the market at bay: exploring the loci of innovation in the cultural industries. Creative Industries Journal, Vol. 30, No. 1, pp. 61-67 (2014).

4. Scott, A. J., The Cultural Economy of Cities. London, Sage (2000).

5. Leslie, D., Rantisi, N. M., Innovation and cultural industries. In Bathelt, H, Cohendet, P, Henn, S, Simon L., (Eds.), The Elgar Companion to Innovation and Knowledge Creation, pp. 244-257, Cheltenham, Edward Elgar Publishing (2017).

6. Oakley, K., O'Connor, J., The Cultural Industries. An Introduction. In Oakley, K., O'Connor, J. (Eds.), The Routledge Companion to the Cultural industries, pp. 1-32, London (2015).

7. Suciu, M. C., Istudor, L., Spinu, D. F., Nasulea, C., Cultural and Creative Economy: Challenges and Opportunities for Romania. In Marginean, S., Ogrean, C., Orastean, R. (Eds.), Emerging Issues in the Global Economy. Springer Proceedings in Business and Economics, pp. 351-361, Cham, Springer (2018).

8. Maslow, A. H., A Theory of Human Motivation. Psychological Review, Vol. 50, No. 4, pp. 370-396 (2012).

9. OECD, Agricultural Policies in OECD Countries: Monitoring and Evaluation 2000: Glossary of Agricultural Policy Terms (2000). Retrieved 13.03.2018, from https://stats.oecd.org/glossary/detail.asp?ID=303

10. Eurostat, Culture statistics - cultural employment (2016). $\begin{array}{llll}\text { Retrieved } & 03 & 13, & \text { 2018, from }\end{array}$ http://ec.europa.eu/eurostat/statistics-

explained/index.php/Culture_statistics_cultural_employment

11. Pratt, A. C., Creative industries and economic evolution, Cheltenham, Edward Elgar Publishing Limited (2011).

12. European Union, Culture Statistics. Luxembourg, Publications Office of the European Union (2016).

13. Eurostat statistics (2017).

14. Rozentale, I., Creative industries during economic recession: the case of Riga. Regional Studies, Regional Science, pp. 329-335 (2014).

15. De Propis, L.:, How are creative industries weathering the crisis? Cambridge Journal of Regions, Economy and Society, Vol. 6, No.1, pp. 23-35 (2013).

16. Florida, R., The Rise of the Creative Class-Revised and Expanded. New York, Basic Books (2014).

17. UNESCO, Cultural Times (2015). Retrieved 15.03.2018, from

https:/en.unesco.org/creativity/sites/creativity/files/cultura 1_times._the_first_global_map_of_cultural_and_creative_i ndustries.pdf

18. Primorac, J., The Position and Perspectives of Cultural and Creative Industries in Southeastern Europe. Medij. istraž., Vol. 20, No. 1, pp. 45-65 (2014). 